\title{
ОСОБЕННОСТИ ЗАЛЕГАНИЯ СНЕЖНОГО ПОКРОВА НА ТЕРРИТОРИИ РЕСПУБЛИКИ БЕЛАРУСЬ
}

\author{
О. П. Мешик', В. А. Морозова², М. В. Борушко
}

\author{
${ }^{1}$ К. т. н., доцент, заведующий кафедрой природообустройства учреждения образования \\ «Брестский государственный технический университет», Брест, Беларусь, е-тail: omeshyk@gmail.com \\ 2 Магистр технических наук, аспирант кафедры природообустройства, старший преподаватель \\ кафедры начертательной геометрии и инженерной графики учреждения образования \\ «Брестский государственный технический университет», Брест, Беларусь, e-mail: vmorozova-brest@mail.ru \\ ${ }_{3}^{3}$ Магистр технических наук, старший преподаватель кафедры иностранных языков учреждения образования \\ «Брестский государственный технический университет», Брест, Беларусь, e-mail: borushko.marina@mail.ru
}

\begin{abstract}
Ресрерат
Выполнен анализ режима залегания снежного покрова на территории Республики Беларусь. Установлены даты образования снежного покрова, продолжительность его залегания за период 1990-2020 гг. Выявленные трансформации по сравнению с периодом 1945-1990 гг. статистически значимы. Продолжительность залегания снежного покрова за рассматриваемый период уменьшилась в среднем на 10-24 дней. При этом, образование снежного покрова происходит позднее в среднем до 8 дней, а его разрушение раньше до 16 дней.
\end{abstract}

Ключевые слова: Беларусь, снежный покров, образование и разрушение снежного покрова, продолжительность залегания.

\section{PECULIARITIES IN THE FORMATION OF SNOW COVER IN BELARUS}

\section{Abstract}

\section{A. P. Meshyk, V. A. Marozava, M. V. Barushka}

There has been performed an analysis of the regime of snow cover formation on the territory of the Republic of Belarus. The authors determine the dates of snow cover formation and the duration of snow lying within 1990-2020. The transformations revealed during this time interval, as compared to the period of 1945-1990, are of statistical importance. The duration of snow lying has reduced by 10-24 days on average. What is more, the snow cover forms 8 days later but destroys 16 days earlier on average.

Keywords: Belarus, snow cover, formation and destruction of snow cover, duration of snow lying.

\section{Введение}

Снег - одно из самых широко распространенных явлений природы, активно воздействующих на общество и экономику в различных регионах мира. Снежным покровом называется слой снега на поверхности земли, сформированный снегопадами. Внутреннее его строение слоистое, что определяется периодическими снегопадами и другими атмосферными осадками, солнечной радиацией, ветром и метаморфизмом снега (возгонка и сублимация снежных кристаллов). Вода в снежном покрове может одновременно находиться в двух (сухой снег) или трех (мокрый снег) фразовых состояниях: твердом, жидком и в виде водяного пара. Высота снежного покрова и его физикомеханические свойства непрерывно изменяются в течение зимы.

Снежный покров играет важную роль в функционировании экосистем. Он оказывает влияние на климат, рельеф, гидрологические и почвообразовательные процессы, жизнь растений и животных. Особенно большое влияние снег оказывает на климат в средних широтах северного полушария, где расположена территория Беларуси. Он в значительной мере определяет характер календарных сезонов, годовой ход температуры воздуха, а также изменения погоды в течение суток.

Наблюдения за снежным покровом осуществляются с целью получения информации о пространственном распределении снежного покрова, динамике его накопления и продолжительности залегания, об условиях таяния и количестве образующейся весной талой снеговой воды [1, 2 и др.]. Основное назначение данных наблюдений связано с изучением климатического и гидрологического режимов территории, составлением агрометеорологических и гидрологических прогнозов, а также с оценкой изменений природной среды (в т. ч. климатических колебаний).

Одними из первых работ по обследованию свойств снега являются труды А. И. Воейкова [3], Г. Д. Рихтера [4], П. П. Кузьмина [5]. В них рассмотрены особенности формирования снега, а также районирование территорий стран бывшего СССР по характеру снежного покрова.

В последние десятилетия XX столетия зафиксировано глобальное потепление климата, что отразилось на ряде климатических показателей, в том числе и на снежном покрове, поэтому большая часть современных работ посвящена как исследованиям влияния потепления климата на характеристики снежного покрова, так и изучению снежного покрова как фактора климатических изменений [6-10 и др.]. Сведения об этих показателях в качестве эмпирической основы необходимы для реализации метеорологической наукой своих основных функций: наблюдения, обработки, анализа и прогноза.

Многие авторы рассматривают особенности снежного покрова для различных территорий, продолжительность его залегания, высоту, снегозапасы и их зависимость от различных климатических характеристик [11-13 и др.]. В ряде исследований говорится о методах дистанционного зондирования земли в определении характеристик снежного покрова, выявлены тенденции к снижению снежного покрова в северном полушарии [14-18 и др.]. В последние годы большое число работ посвящено влиянию изменчивости параметров снежного покрова на промерзание грунта и анализу связей с атмосферной циркуляцией [19-21 и др.].

Территория Республики Беларусь обладает весьма выраженными контрастами в распределении и режиме снежного покрова. Особенность формирования снежного покрова в современных условиях - влияние частых и длительных оттепелей в зимний период, в результате чего поверхностные запасы влаги переходят в почвогрунты. Данные изменения приводят к существенному уменьшению в течение зимы, а порой и к исчезновению снежного покрова, особенно в южных районах, а максимальная высота снежного покрова смещается на более поздние сроки [22]. В целом снежный покров характеризуется значительной неустойчивостью.

Наиболее полное обобщение характеристик снежного покрова территории Беларуси выполнено в работе [23]. Однако приводимые здесь данные и карты, в большей степени, характеризуют период до современного потепления. Многие выполненные работы посвящены оценкам современных трансформаций таких характеристик снежного покрова, как запас воды в снеге, плотность и высота залегания [24, 25 и др.]. В то же время очень мало работ отражают особенности режима залегания снежного покрова и его изменчивость. Имеющиеся работы затрагивают территории отдельных регионов Беларуси [26], поэтому включение в обобщение всей исследуемой территории актуально и способно обеспечить ее качественное гидрологоклиматическое районирование. Например, при расчете параметров весеннего половодья, планировании снегоуборки на дорогах, нормировании снеговых нагрузок на конструкции зданий и сооружений, проведении сельскохозяйственных работ и др. 


\section{Материалы и методы}

Объектом исследования в работе являются данные метеорологических наблюдений за период с 1990 по 2020 гг., характеризующие даты первого появления, образования, разрушения, последнего схода снежного покрова, а также продолжительность его залегания [27]. Предмет исследования - количественные оценки и закономерности пространственно-временного распределения характеристик снежного покрова на территории Беларуси. Применяемые методы исследования включают: методы статистической обработки экспериментальных данных, пространственно-временной анализ, аналитические расчеты, картографирование.

\section{Режим залегания снежного покрова}

Режим залегания снежного покрова характеризуется данными наблюдений ближайших к району исследований метеостанций. Число дней со снежным покровом, даты его появления и схода представляют собой наиболее общие характеристики режима. Днем со снежным покровом считается день, когда более половины видимой окрестности покрыто снегом, причем не имеет значение, является залегание устойчивым или нет. Дата появления снежного покрова это первый день, когда он отмечен (независимо от продолжительности последующего залегания), дата последнего схода - день следующий за последним днем со снежным покровом. В отдельные годы дать появления снежного покрова даже на близкорасположенных метеостанциях могут сильно отличаться, так как и даты последнего схода.

В таблице 1 приведены даты образования и разрушения снежного покрова, число дней со снежным покровом за 1990-2020 гг., для сравнения в таблице 2 даются те же характеристики за годы обобщений 1945-1990 [28].

Устойчивым принято считать снежный покров, который лежит в течение холодного периода года не менее одного месяца с перерывами в общей сложности не более трех дней подряд в месяце. При этом перерыву в один день в начале (конце) зимы должно предшествовать (за перерывом следовать) залегание снежного покрова не менее 5 дней, а перерыву в 2-3 дня - не менее 10 дней. За дату образования устойчивого снежного покрова принимается первый день периода с устойчивым снежным покровом, за дату разрушения - день следующий за последним днем с устойчивым снежным покровом. Точки в таблицах 1 и $2(\bullet)$ означают, что на метеостанции устойчивый снежный покров отсутствовал хотя бы в одну из зим. Средняя дата считалась только за годы наличия устойчивого снежного покрова. Число дней со снежным покровом подсчитывалось независимо от того, было ли его залегание устойчивым или нет, поэтому это число больше, чем разность между средними датами образования и разрушения устойчивого снежного покрова, но меньше, чем разность между средними датами первого появления и последнего схода, так как между этими датами всегда есть дни, когда снежный покров отсутствует.

Для оценки пространственной изменчивости на территории Беларуси исследуемых характеристик снежного покрова нами выполнено их районирование (рисунки 1-6) за период осреднения 1990-2020 гг. Использована методика построения карт в изолиниях, апробированная нами ранее на картировании сильных снегопадов, метелей и их повторяемостей [29], запасов воды в снеге, плотностей и высоты залегания, используемых при нормировании снеговых нагрузок на конструкции зданий и сооружений [30] и оценки параметров весеннего половодья [31].

Средние даты появления снежного покрова за рассматриваемый период на территории Беларуси находятся в диапазоне 22.10-06.11 (таблица 1) - 15 дней и распределяются с северо-запада на юговосток (рисунок 1). Самая ранняя дата первого появления снежного покрова зафиксирована 30.09.1997 в Витебске, самая поздняя 17.12.2001 в Бресте. Устойчивый снежный покров образуется через 45-55 дней после первых снегопадов, в течение этого периода наблюдается неустойчивая погода с многократным числом фазовых переходов. К 13.12-28.12 (средние даты образования устойчивого снежного покрова) земная поверхность выхолаживается, поступают холодные воздушные массы и происходит снегонакопление. На рисунке 7 показаны отклонения в днях от средних значений характеристик снежного покрова для метеостанции Минск. Отклонения от среднего носят знакопеременный характер до \pm 28 дней для появления первого снега (рисунок 7а) и более \pm 35 - для образования устойчивого снежного покрова (рисунок 7в). В отдельные зимы устойчивый снежный покров не образовывается вообще. Для Бреста это происходит каждую вторую зиму, а для Витебска - в 13 \% лет.

Таблица 1 - Даты образования и разрушения снежного покрова, число дней со снежным покровом (годы обобщения средних значений 1990-2020 гг.)

\begin{tabular}{|c|c|c|c|c|c|c|c|c|c|c|c|c|c|c|c|}
\hline \multirow{3}{*}{$\left|\begin{array}{l}№ \\
\text { ח/ח }\end{array}\right|$} & \multirow{3}{*}{ Станция } & \multirow{3}{*}{\begin{tabular}{|c|} 
Число \\
дней со \\
снежным \\
покровом \\
\end{tabular}} & \multirow{3}{*}{$\begin{array}{c}\text { Число дней } \\
\text { устойчивого } \\
\text { снежного } \\
\text { покрова } \\
\end{array}$} & \multirow{2}{*}{\multicolumn{3}{|c|}{ Дата первого появления }} & \multicolumn{3}{|c|}{ Дата образования } & \multicolumn{3}{|c|}{ Дата разрушения } & \multirow{2}{*}{\multicolumn{3}{|c|}{ Дата последнего схода }} \\
\hline & & & & & & & & & Тойчивогс & залегания & & & & & \\
\hline & & & & средняя & $\begin{array}{l}\text { самая } \\
\text { ранняя }\end{array}$ & $\begin{array}{c}\text { самая } \\
\text { поздняя }\end{array}$ & средняя & $\begin{array}{l}\text { самая } \\
\text { ранняя }\end{array}$ & $\begin{array}{c}\text { самая } \\
\text { поздняя }\end{array}$ & средняя & $\begin{array}{l}\text { самая } \\
\text { ранняя }\end{array}$ & $\begin{array}{c}\text { самая } \\
\text { поздняя }\end{array}$ & средняя & $\begin{array}{l}\text { самая } \\
\text { ранняя }\end{array}$ & $\begin{array}{c}\text { самая } \\
\text { поздняя }\end{array}$ \\
\hline 1 & Витебск & 111 & 92 & 22.10 & 30.09 .1997 & 16.11 .2004 & 13.12 & 08.11 .1998 & - & 15.03 & - & 14.04 .2013 & 19.04 & 01.04.2004 & 12.05 .2000 \\
\hline 2 & Минск & 99 & 84 & 28.10 & 01.10 .1998 & 24.11 .2000 & 15.12 & 09.11 .1993 & - & 09.03 & - & 14.04 .2013 & 19.04 & 27.03.2004 & 13.05 .2000 \\
\hline 3 & Гродно & 76 & 58 & 03.11 & 05.10 .1998 & 06.12 .2011 & 26.12 & 12.11.1998 & - & 21.02 & - & 15.04.2013 & 09.04 & 08.03.2004 & 04.05.2011 \\
\hline 4 & Могилев & 99 & 82 & 01.11 & 24.09.1997 & 22.11 .2000 & 15.12 & 10.11.1998 & - & 06.03 & - & 14.04 .2013 & 12.04 & 22.03.2005 & 12.05 .2000 \\
\hline 5 & Брест & 67 & 58 & 06.11 & 04.10 .1998 & 17.12.2001 & 28.12 & 16.11.1998 & • & 22.02 & • & 11.04 .2013 & 09.04 & 17.03.2014 & 04.05 .2011 \\
\hline 6 & Гомель & 87 & 69 & 01.11 & 01.10 .1998 & $\begin{array}{l}26.11 .2014 \\
26.11 .2015\end{array}$ & 21.12 & $\begin{array}{l}09.11 .1993 \\
09.11 .1998\end{array}$ & - & 28.02 & - & 06.04.2013 & 12.04 & \begin{tabular}{|l|}
26.03 .2001 \\
26.03 .2019
\end{tabular} & 05.05.1999 \\
\hline
\end{tabular}

Таблица 2 - Даты образования и разрушения снежного покрова, число дней со снежным покровом (годы обобщения средних значений 1945-1990 гг.) [28]

\begin{tabular}{|c|c|c|c|c|c|c|c|c|c|c|c|c|c|c|c|}
\hline \multirow{3}{*}{$\begin{array}{l}№ \\
\Pi / \Pi\end{array}$} & \multirow{3}{*}{ Станция } & \multirow{3}{*}{$\begin{array}{c}\text { Число } \\
\text { дней со } \\
\text { снежным } \\
\text { покровом } \\
\end{array}$} & \multirow{3}{*}{$\begin{array}{c}\text { Число дней } \\
\text { устойчивого } \\
\text { снежного } \\
\text { покрова }\end{array}$} & \multirow{2}{*}{\multicolumn{3}{|c|}{ Дата первого появления }} & \multicolumn{3}{|c|}{ Дата образования } & \multirow{2}{*}{\multicolumn{3}{|c|}{$\begin{array}{l}\text { Дата разрушения } \\
\text { гания }\end{array}$}} & \multirow{2}{*}{\multicolumn{3}{|c|}{ Дата последнего схода }} \\
\hline & & & & & & & & & ОЙчивОГО & & & & & & \\
\hline & & & & средняя & $\begin{array}{l}\text { cam } \\
\text { paH }\end{array}$ & $\begin{array}{c}\text { самая } \\
\text { поздняя } \\
\end{array}$ & средняя & $\begin{array}{l}\text { самая } \\
\text { ранняя }\end{array}$ & \begin{tabular}{|c|} 
самая \\
поздняя \\
\end{tabular} & дняя & \begin{tabular}{|c|} 
самая \\
ранняя \\
\end{tabular} & $\begin{array}{c}\text { самая } \\
\text { поздняя }\end{array}$ & । & $\begin{array}{l}\text { самая } \\
\text { ранняя }\end{array}$ & $\begin{array}{c}\text { самая } \\
\text { поздняя }\end{array}$ \\
\hline 1 & Витебск & 121 & 109 & & 07.1 & 27.11 & 12 & 30.10. & - & 3 & - & 16.04 .1956 & 4 & 16.03.1990 & 953 \\
\hline 2 & & 114 & 101 & & & & .12 & 29.10 .1 & - & 20.03 & - & 11.04 & 11.04 & & \\
\hline 3 & ОДНО & 88 & 7 & & & & 27.12 & 17.11.1909 & - & 09.03 & - & 14.04 & 4 & & \\
\hline 4 & огил & 119 & 106 & & 77 & 1 & 12 & 29.10 .1 & & 22. & $\bullet$ & 19.0 & 12. & 14 & 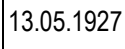 \\
\hline 5 & 10 & 19 & 08 & & 73 & 2 & 12 & 18.11 & 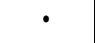 & 0.6 & ${ }^{\circ}$ & 07.0 & 30. & 03 & $\mid<6$ \\
\hline 0 & Гомель & 101 & 88 & 14.11 & 26.09 .1906 & 19.12.1953 & 18.12 & 30.10 .1956 & • & 15.03 & - & 14.04.1907 & 31.03 & 08.02.1974 & 06.05 .19 \\
\hline
\end{tabular}


Вестник Брестского государственного технического университета. 2021

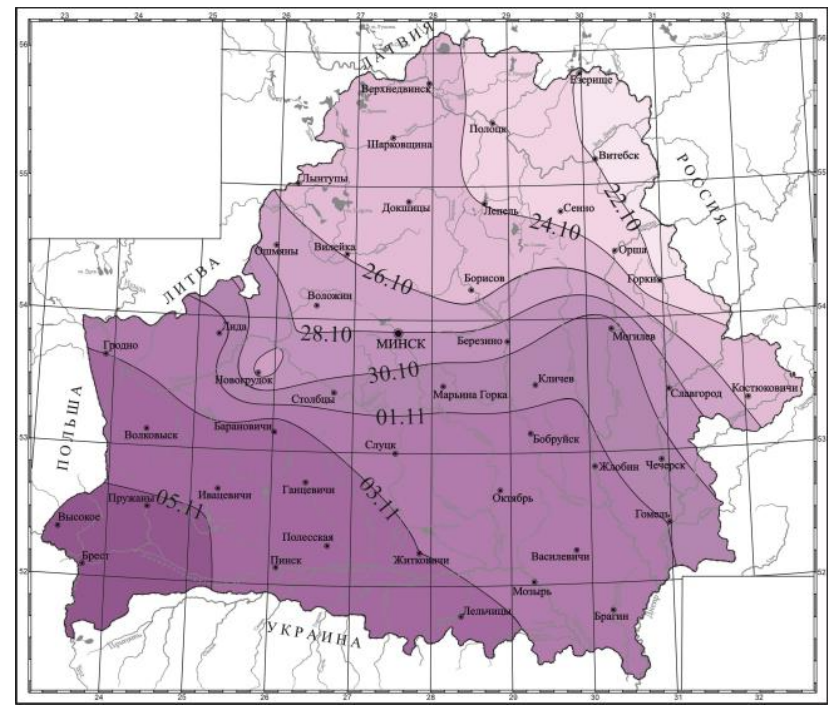

Рисунок 1 - Дата первого появления снежного покрова



Рисунок 3 - Дата образования устойчивого снежного покрова



Рисунок 5 - Число дней со снежным покровом

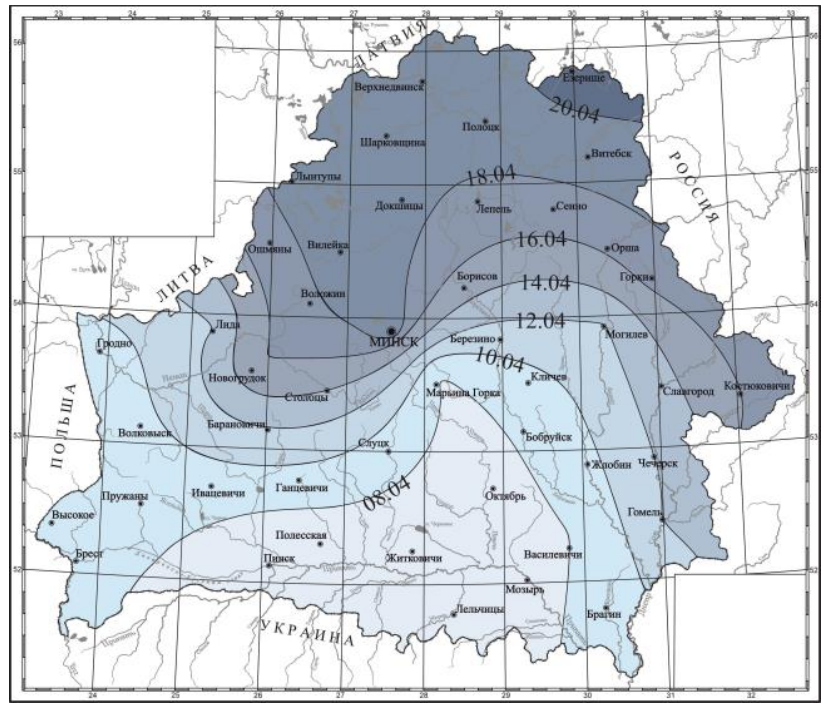

Рисунок 2 - Дата последнего схода снежного покрова

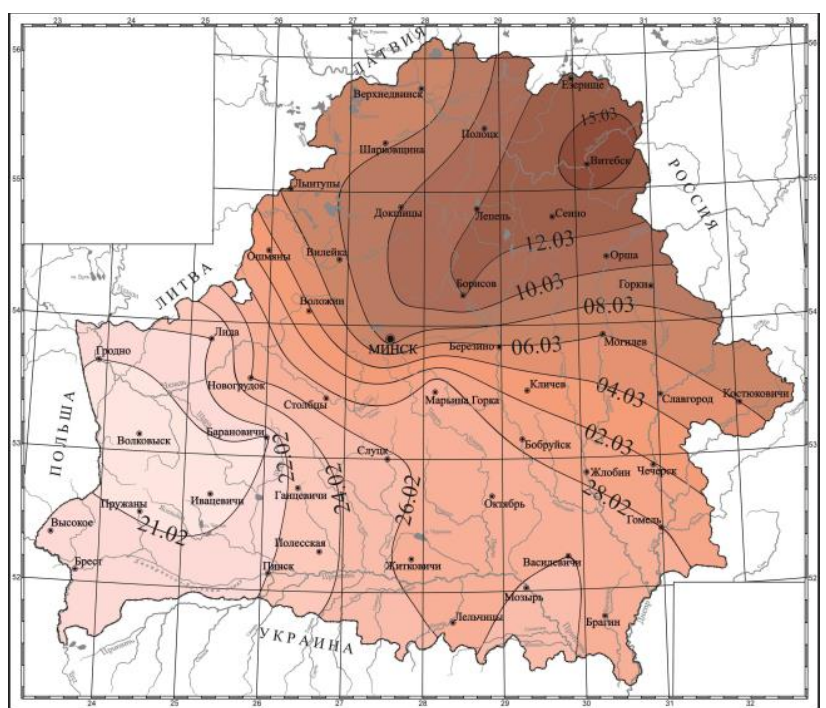

Рисунок 4 - Дата разрушения устойчивого снежного покрова

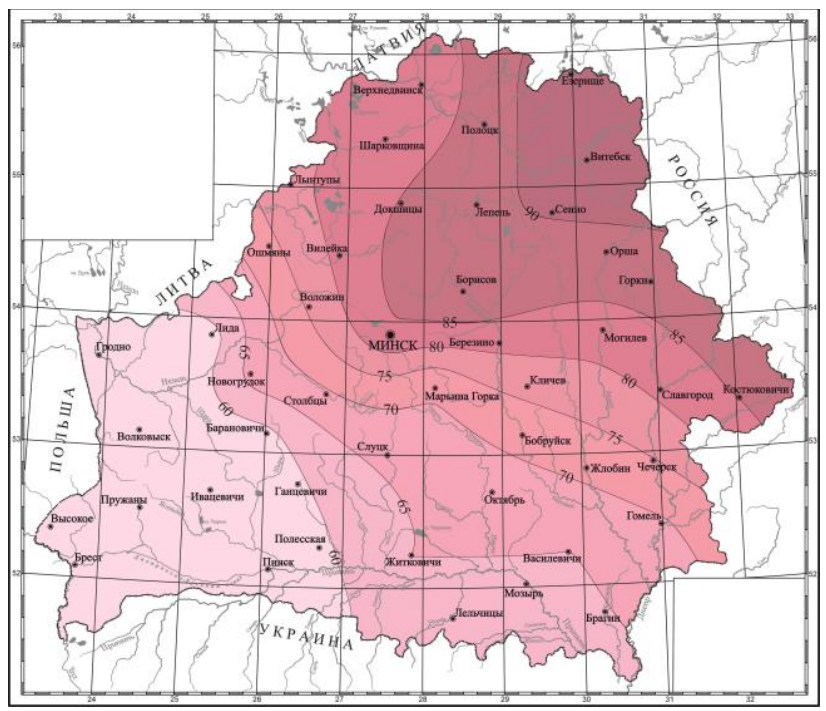

Рисунок 6 - Продолжительность залегания устойчивого снежного покрова, дней 
Число дней со снежным покровом также распределяется по направлению северо-восток - юго-запад, от 111 дней в Витебске, до 67 - в Бресте (рисунок 5, таблица 1). Однако имеют место значительные отклонения по годам, например, +73 дня и - 40 дней в Минске (рисунок 7д), при среднем значении 99 дней. Наименьшее число дней со снежным покровом в рассматриваемом периоде - 11, в Бресте. Наибольшее число дней превысило 130 практически по всем метеостанциям в 1995-1996 гг. Как было сказано ранее, устойчивый снежный покров может не сформироваться, однако его средняя продолжительность составляет 58 (Брест, Гродно) - 92 (Витебск) дней. Самая ранняя дата образования устойчивого снежного покрова зафиксирована в Витебске 08.11.1998, самая поздняя дата разрушения - в Гродно 15.04.2013 (таблица 1). В отличие от средних дат, самые ранние и самые поздние даты образования и разрушения устойчивого снежного не имеют значительных территориальных различий и составляют 5-9 дней.

Отклонения от средних значений характеристик режима снежного покрова за последний 30-летний период (рисунок 7) в Минске показывают, что в основном они носят случайный характер, однако образование устойчивого снежного покрова с 2009-2010 гг. происходит позднее до 35 и более дней (рисунок 7в). С 2013- 2014 гг. имеет место и более позднее разрушение устойчивого снежного покрова на 10-30 дней (рисунок 7г). В целом по метеостанции Минск прослеживается достаточно четкий линейный тренд увеличения числа дней со снежным покровом.



a)



B)



д)

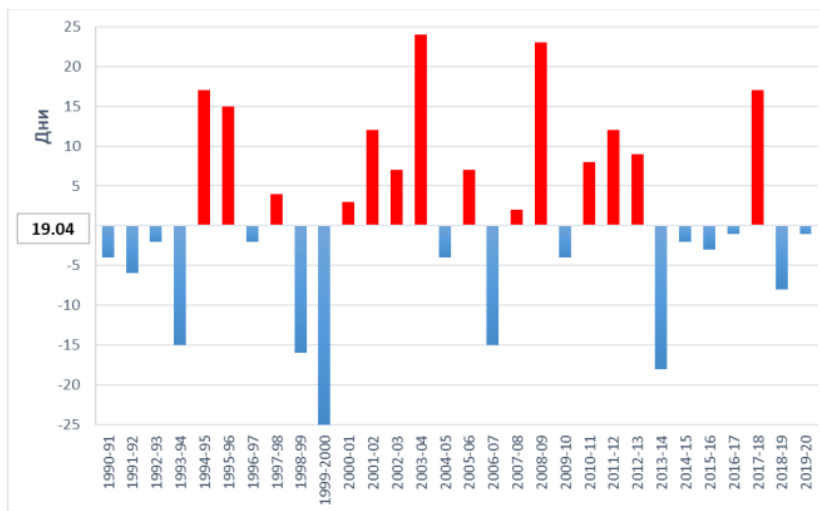

б)

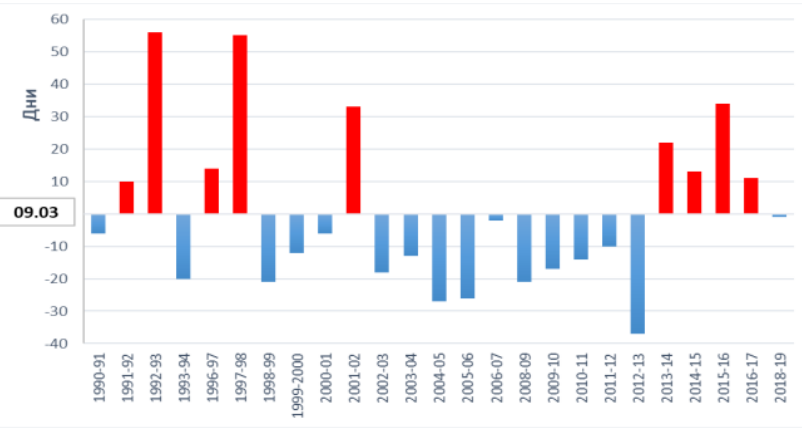

г)

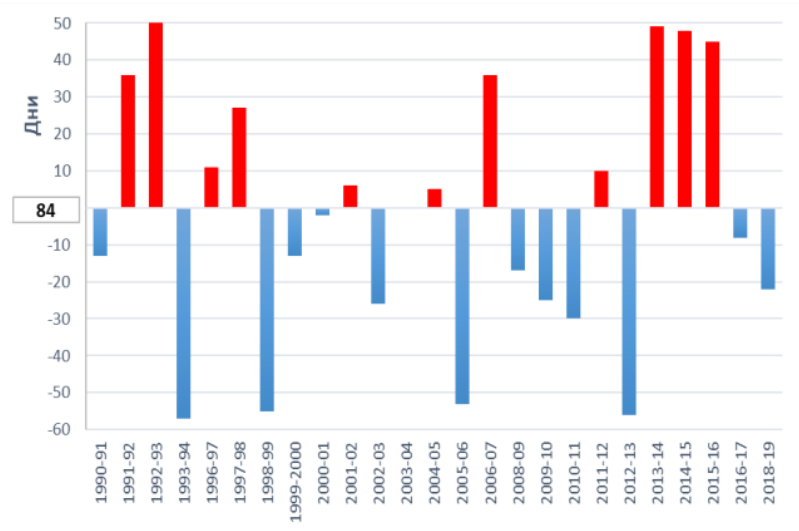

e)

а - даты первого появления снежного покрова; б - даты последнего схода снежного покрова; в - даты образования устойчивого снежного покрова; г - дата разрушения устойчивого снежного покрова; д - числа дней со снежным покровом; е - продолжительности залегания устойчивого снежного покрова

Рисунок 7 - Отклонения (дни) от средних значений характеристик режима снежного покрова за период 1990-2020 гг. по метеостанции Минск 
Вестник Брестского государственного технического университета. 2021

Практический интерес представляет установление трансформаций характеристик снежного покрова в многолетнем периоде. В этой связи выполнено сравнение результатов, характеризующих изменчивость дат и продолжительности залегания снежного покрова за последнее тридцатилетие (1990-2020 гг.) по сравнению с периодом 1945-1990 гг. Результаты обобщений таблиц 1 и 2 сведены в таблицу 3.

Таблица 3 - Отклонения за период 1990-2020 гг. (таблица 1) по отношению к 1945-1990 гг. (таблица 2) характеристик залегания снежного покрова на территории Беларуси

\begin{tabular}{|c|c|c|c|c|c|c|}
\hline \multirow{3}{*}{ Станция } & \multirow{3}{*}{$\begin{array}{c}\text { Число } \\
\text { дней со } \\
\text { снежным } \\
\text { покро- } \\
\text { вом }\end{array}$} & \multirow{3}{*}{$\begin{array}{c}\text { Число } \\
\text { дней } \\
\text { устой } \\
\text { чиво- } \\
\text { го } \\
\text { снеж- } \\
\text { ного } \\
\text { по- } \\
\text { крова }\end{array}$} & \multicolumn{4}{|c|}{ Отклонения дат } \\
\hline & & & \multirow{2}{*}{\begin{tabular}{|c} 
появле- \\
ние \\
снежного \\
покрова
\end{tabular}} & \multicolumn{2}{|c|}{$\begin{array}{c}\text { устойчивый снежный } \\
\text { покров } \\
\end{array}$} & \multirow{2}{*}{$\begin{array}{c}\text { сход } \\
\text { снежно- } \\
\text { го по- } \\
\text { крова }\end{array}$} \\
\hline & & & & $\begin{array}{c}\text { образова- } \\
\text { ние }\end{array}$ & $\begin{array}{l}\text { разруше- } \\
\text { ние }\end{array}$ & \\
\hline Витебск & -10 & -17 & -13 & 7 & -9 & 9 \\
\hline Минск & -15 & -17 & -10 & 5 & -11 & 8 \\
\hline Гродно & -12 & -15 & -14 & -1 & -16 & 6 \\
\hline Могилев & -20 & -24 & -5 & 8 & -16 & 0 \\
\hline Брест & -12 & -10 & -15 & 0 & -11 & 10 \\
\hline Гомель & -14 & -19 & -13 & 3 & -15 & 12 \\
\hline
\end{tabular}

Как видно из таблицы 3, на всей территории Беларуси появление первого снежного покрова происходит раньше на 5-15 дней, а сход последнего снега до 12 дней позднее. В то же время число дней со снежным покровом сократилось на 10-20 дней. Все это говорит о росте экстремальности климата и повторяемости опасных метеорологических явлений [29], что согласуется с общей теорией потепления климата. В зимний период снежный покров неустойчивый, происходит его многократное таяние и обратное формирование. Все это приводит к увеличению зимнего стока, что подтверждается проведенными научными исследованиями [1, 2 и др.]. Однако образование устойчивого снежного покрова, за исключением Бреста и Гродно, происходит на 3-8 дней позднее, а его разрушение на 9-16 дней раньше на всей исследуемой территории. Продолжительность залегания устойчивого снежного покрова сократилась в Беларуси на 10-24 дней и составляет в среднем 58 дней в Бресте и Гродно и является самой большой - 92 дня в Витебске.

\section{Заключение}

Наблюдается четкая тенденция сокращения продолжительности залегания устойчивого снежного покрова в последнее тридцатилетие. Однако первое появление снежного покрова случается на 5-15 дней раньше - 22.10-06.11. Сход снежного покрова происходит позднее до 12 дней, средняя дата последнего схода - 09.04-19.04. С одной стороны, это свидетельствует о явном потеплении климата в зимний период и интенсивном снеготаянии, с другой стороны, первый снег мы сейчас можем наблюдать уже в сентябре, а последний еще в мае, что говорит о росте экстремальности режима снежного покрова исследуемой территории.

Построенные карты (рисунки 1-6) могут использоваться в учебном процессе при подготовке специалистов-геоэкологов, при оценке параметров дружности весеннего половодья, в ходе нормирования снеговых нагрузок на конструкции зданий и сооружений, оценки климатических рисков при ведении сельскохозяйственного производства, в системе жилищно-коммунального хозяйства при планировании снегоуборки и др.

\section{Список цитированных источников}

1. Мешик, О. П. Роль снежного покрова в формировании весеннего половодья на реках Беларуси / О. П. Мешик, В. А. Морозова, М. В. Борушко // Мелиорация. - 2020. - № 4 (94). - С. 35-40.
2. Meshyk, A., Barushka, M. \& Marozava, V. Snow as a contributor to spring flooding in Belarus. Environ Sci Pollut Res 28, 18826-18836 (2021). https://doi.org/10.1007/s11356-020-09638-8.

3. Воейков, А. И. Снежный покров, его влияние на почву, климат и погоду и способы исследования / [Соч.] Д. чл. А. И. Воейкова ; Под ред. И. Мушкетова. - 2-е изд., испр. и значительно доп. СПб. : Тип. Имп. Акад. наук, 1889. - [2], IV, 213 с. : табл. - (Записки имп. рус. геогр. о-ва по общ. геогр.; т. XVIII, №2).

4. Рихтер, Г.Д. Снежный покров, его формирование и свойства / Г. Д. Рихтер ; [отв. ред. А. А. Григорьев]. - М. ; Л. : Изд-во АН СССР, 1945. - 120 С. - (АН СССР. Научно-популярная серия).

5. Кузьмин, П. П. Формирование снежного покрова и методы определения снегозапасов / П. П. Кузьмин ; Гл. упр. гидрометеорологической службы при Совете Министров СССР. Гос. ордена Труд. Красного Знамени гидрол. ин-т. - Л. : Гидрометеоиздат, 1960. - $171 \mathrm{C}$.

6. Валуев, В. Е. Изученность и статистические оценки снегозапасов / В. Е. Валуев, О. П. Мешик // Вестник Брестского государственного технического университета. - 2013. - № 2: Водохозяйственное строительство, теплоэнергетика и геоэкология. - С. 8-11.

7. Максютова, Е. В. Режим снежного покрова Предбайкалья в изменяющемся климате [Электронный ресурс] / Е. В. Максютова // Лёд и Снег. - 2017. - № 57(2). - С. 221-230. https://doi.org/10.15356/2076-6734-2017-2-221-230.

8. Сосновский, А. В. Динамика снегозапасов на равнинной территории России в лесу и в поле при климатических изменениях [Электронный ресурс] / А. В. Сосновский, Н. И. Осокин, Г. А. Черняков // Лёд и Снег. - 2018. - № 58(2). - С. 183-190. - Режим доступа: https://doi.org/10.15356/2076-6734-2018-2-183-190.

9. Титкова, Т. Б. Изменчивость зимнего стока реки Ока в зависимости от изменения климата [Электронный ресурс] / Т. Б. Титкова // Лёд и Снег. - 2018. - № 58(2). - С. 191-198. - Режим доступа: https://doi.org/10.15356/2076-6734-2018-2-191-198.

10. Mandar, R. Trivedi. Projecting Climate Change Impacts on Mountain Snow Cover in Central Scotland from Historical Patterns / Mandar R. Trivedi, Mervyn K. Browne, Pamela M. Berry, Terence P. Dawson \& Michael D. Morecroft (2007) // Arctic, Antarctic, and Alpine Research, 39:3, 488-499. https://doi.org/10.1657/1523-0430(06006)[TRIVEDI]2.0.CO;2.

11. Осокин, Н. И. Динамика параметров снежного покрова, влияющих на устойчивость многолетней мерзлоты на архипелаге Шпицберген / Н. И. Осокин, А. В. Сосновский // Лёд и Снег. 2016. - № 56(2). - C. 189-198. https://doi.org/10.15356/2076-67342016-2-189-198.

12. Воропай, Н. Н. Особенности распределения снежного покрова на побережье озера Байкал [Электронный ресурс] / Н. Н. Воропай, В. К. Власов // Лёд и Снег. - 2017. - № 57(3). - С. 355-364. - Режим доступа: https://doi.org/10.15356/2076-6734-2017-3-355-364.

13. Ефремов, Ю. В. Снежный покров на Лагонакском нагорье (Западный Кавказ) [Электронный ресурс] / Ю. В. Ефремов, А. В. Зимницкий // Лёд и Снег. - 2017. - № 57(3). - С. 365-372. Режим доступа: https://doi.org/10.15356/2076-6734-2017-3-365-372.

14. Калашникова, О. Ю. Использование наземных и спутниковых данных о снежном покрове для прогноза стока реки Нарын [Электронный ресурс] / О. Ю. Калашникова, А. А. Гафуров // Лёд и Снег. - 2017. - № 57(4). - С. 507-517. - Режим доступа: https://doi.org/10.15356/2076-6734-2017-4-507-517.

15. Henkel, P., Koch, F., Appel, F., Bach, H., Prasch, M., Schmid, L., et al. (2018). Snow water equivalent of dry snow derived from GNSS carrier phases. IEEE Trans. Geosci. Remote Sens. 56, 3561-3572. https://doi.org/10.1109/TGRS.2018.2802494.

16. Appel, F., Koch, F., Rösel, A., Klug, P., Henkel, P., Lamm, M., et al. (2019). Advances in snow hydrology using a combined approach of GNSS in situ stations, hydrological modelling and earth observation-a case study in Canada. Geosciences 9:44. https://doi.org/ $10.3390 /$ geosciences 9010044 .

17. Masahiro, Hori. A 38-year (1978-2015) Northern Hemisphere daily snow cover extent product derived using consistent objective criteria from satellite-borne optical sensors / Masahiro Hori, Konosuke Sugiura, Kazufumi Kobayashi, Teruo Aoki, Tomonori Tanikawa, Katsuyuki Kuchiki, Masashi Niwano, Hiroyuki Enomoto // Remote Sensing of Environment Volume 191, 15 March 2017, Pages 402-418. 
18. Dai, L., Che, T., Ding, Y., and Hao, X. (2017) Evaluation of snow cover and snow depth on the Qinghai-Tibetan Plateau derived from passive microwave remote sensing. The Cryosphere. 11. 19331948. https://doi.org/10.5194/tc-11-1933-2017.

19. Китаев, Л. М. Сезонная динамика температуры воздуха, снегозапасов и промерзания почвы в центральной части ВосточноЕвропейской равнины [Электронный ресурс] / Л. М. Китаев, В. А. Аблеева, Ж. А. Асаинова, А. С. Желтухин, Е. Д. Коробов // Лёд и Снег. - 2017. - № 57(4). - С. 518-526. - Режим доступа: https://doi.org/10.15356/2076-6734-2017-4-518-526.

20. Шерстюков, А. Б. Оценка влияния снежного покрова на температуру поверхности почвы по данным наблюдений / А. Б. Шерстюков, О. А. Анисимов // Метеорология и гидрология. - 2018. № 2. - C.17-25.

21. Дюкарев, Е. А. Влияние температуры воздуха и снежного покрова на характеристики сезонномерзлого слоя почвогрунтов / Е. А. Дюкарев // Криосфера Земли. - 2015. - т. XIX, № 3. - С. 45-51.

22. Логинов, В.Ф. Весенние половодья на реках Беларуси: пространственно-временные колебания и прогноз / В. Ф. Логинов, А. А. Волчек, Ан. А. Волчек. - Минск : Беларуская навука, 2014. $244 \mathrm{C}$.

23. Логинов, В. Ф. Климат Беларуси / В. Ф. Логинов. - Минск : Институт геологических наук АН Беларуси, 1996. - 234 с.

24. Мешик, О. П. Особенности внутригодового хода характеристик снежного покрова территории Беларуси / О. П. Мешик, В. А. Морозова, М. В. Борушко // Collection of the International scientific and practical conference "Water resources management in the context of globalization», dedicated to the $105^{\text {th }}$ anniversary of the birth of Professor L. Y. Tazhibaev. - Almaty : KazNARU, 2021. P. 51-55.

25. Мешик, О. П. Исследование трансформации характеристик снежного покрова Беларуси картографическими методами / О. П. Мешик, В. А. Морозова, М. В. Борушко // Матеріали міжнародної науково-практичної інтернет-конференції «Сучасний стан та перспективи розвитку меліорації земель» : до дня пам'яті доктора географічних наук, профресора Литовченка О. Ф., 30 листопада 2020 р. - Дніпро : ДДАЕУ, 2020. - С. 14-17.

26. Шелест, Т. А. Изменения характеристик снежного покрова Брестской области в современных условиях потепления климата / Т. А. Шелест, И. В. Шваюк // Природные и культурные памятники и основные проблемы состояния окружающей среды Беларуси и сопредельных стран : межвузовский сб. науч. работ студентов, магистрантов, аспирантов и преподавателей географических фак. БГУ и БрГУ им. А. С. Пушкина, фак. экологической медицины МГЭИ им. А. Д. Сахарова БГУ, биологического фак. ВитГУ: в 2 ч. / БГУ [и др. ; науч. ред. Я. К. Еловичева]. - Минск : БГУ, 2019. - С. 560-569.

27. Климатический кадастр Республики Беларусь. Метеорологический ежемесячник. - Минск : Республиканский центр по гидрометеорологии, контролю радиоактивного загрязнения и мониторингу окружающей среды, 1979-2020 гг.

28. Снежный покров. Часть II // Климатический справочник [Электронный ресурс]. - 2010. - Режим доступа : https://www.pogoda.by/climat-directory/?page=299. - Дата доступа : 10.05.2021.

29. Volchak, A. Atlas: Weather hazards in Belarus / A. Volchak, Y. Mazhayskiy, A. Meshyk [et al.]. - Moscow : All-Russian Research Institute for Hydraulic Engineering and Land Reclamation, 2017. - 70 p.

30. Тур, В. В. Картографирование основных характеристик снегового покрова по результатам комплексной статистической обработки данных метеорологических наблюдений / В. В. Тур, В. Е. Валуев, С. С. Дереченник, О. П. Мешик // Вестник Брестского государственного технического университета. - 2008. - № 2: Водохозяйственное строительство и теплоэнергетика. - С. 2-10.

31. Meshyk, Aleh. Mapping the Characteristics of Snow Cover in Belarus / Aleh Meshyk, Viktoryia Marozava, Maryna Barushka // 2020 International Conference on Building Energy Conservation, Thermal Safety and Environmental Pollution Control (ICBTE 2020) / E3S Web Conf. Volume 212, 2020. - Brest, Belarus, October 29-30, 2020. https://doi.org/10.1051/e3sconf/202021201013.

\section{References}

1. Meshik, O. P. Rol' snezhnogo pokrova $v$ formirovanii vesennego polovod'ya na rekah Belarusi / O. P. Meshik, V. A. Morozova, M. V. Borushko // Melioraciya. - 2020. - № 4 (94). - S. 35-40.

2. Meshyk, A., Barushka, M. \& Marozava, V. Snow as a contributor to spring flooding in Belarus. Environ Sci Pollut Res 28, 18826-18836 (2021). https://doi.org/10.1007/s11356-020-09638-8.

3. Voejkov, A. I. Snezhnyj pokrov, ego vliyanie na pochvu, klimat i pogodu i sposoby issledovaniya / [Soch.] D. chl. A. I. Voejkova ; Pod red. I. Mushketova. - 2-e izd., ispr. i znachitel'no dop. - SPb. : Tip. Imp. Akad. nauk, 1889. - [2], IV, 213 c. : tabl. - (Zapiski imp. rus. geogr. o-va po obshch. geogr.; t. XVIII, №2)

4. Rihter, G. D. Snezhnyj pokrov, ego formirovanie i svojstva / G. D. Rihter ; [otv. red. A. A. Grigor'ev]. - M. ; L. : Izd-vo AN SSSR, 1945. - 120 s. - (AN SSSR. Nauchno-populyarnaya seriya).

5. Kuz'min, P. P. Formirovanie snezhnogo pokrova i metody opredeleniya snegozapasov / P. P. Kuz'min ; Gl. upr. gidrometeorologicheskoj sluzhby pri Sovete Ministrov SSSR. Gos. ordena Trud. Krasnogo Znameni gidrol. in-t. - L. : Gidrometeoizdat, 1960. - 171 s.

6. Valuev, V. E. Izuchennost' i statisticheskie ocenki snegozapasov / V. E. Valuev, O. P. Meshik // Vestnik Brestskogo gosudarstvennogo tekhnicheskogo universiteta. - 2013. - № 2: Vodohozyajstvennoe stroitel'stvo, teploenergetika i geoekologiya. - S. 8-11.

7. Maksyutova, E. V. Rezhim snezhnogo pokrova Predbajkal'ya v izmenyayushchemsya klimate [Elektronnyj resurs] / E. V. Maksyutova // Lyod i Sneg. - 2017. - № 57(2). - S. 221-230. https://doi.org/10.15356/2076-6734-2017-2-221-230.

8. Sosnovskij, A. V. Dinamika snegozapasov na ravninnoj territorii Rossii v lesu i v pole pri klimaticheskih izmeneniyah [Elektronnyj resurs] / A. V. Sosnovskij, N. I. Osokin, G. A. CHernyakov // Lyod i Sneg. 2018. - № 58(2). - S. 183-190. - Rezhim dostupa: https://doi.org/10.15356/2076-6734-2018-2-183-190.

9. Titkova, T. B. Izmenchivost' zimnego stoka reki Oka v zavisimosti ot izmeneniya klimata [Elektronnyj resurs] / T. B. Titkova // Lyod i Sneg. 2018. - № 58(2). - S. 191-198. - Rezhim dostupa: https://doi.org/10.15356/2076-6734-2018-2-191-198.

10. Mandar, R. Trivedi. Projecting Climate Change Impacts on Mountain Snow Cover in Central Scotland from Historical Patterns / Mandar R. Trivedi, Mervyn K. Browne, Pamela M. Berry, Terence P. Dawson \& Michael D. Morecroft (2007) // Arctic, Antarctic, and Alpine Research, 39:3, 488-499. https://doi.org/10.1657/1523-0430(06-006)[TRIVEDI]2.0.CO;2.

11. Osokin, N. I. Dinamika parametrov snezhnogo pokrova, vliyayushchih na ustojchivost' mnogoletnej merzloty na arhipelage SHpicbergen / N. I. Osokin, A. V. Sosnovskij // Lyod i Sneg. - 2016. № 56(2). - S. 189-198. https://doi.org/10.15356/2076-6734-2016-2189-198.

12. Voropaj, N. N. Osobennosti raspredeleniya snezhnogo pokrova na poberezh'e ozera Bajkal [Elektronnyj resurs] / N. N. Voropaj, V. K. Vlasov // Lyod i Sneg. - 2017. - № 57(3). - S. 355-364. Rezhim dostupa: https://doi.org/10.15356/2076-6734-2017-3-355-364.

13. Efremov, YU. V. Snezhnyj pokrov na Lagonakskom nagor'e (Zapadnyj Kavkaz) [Elektronnyj resurs] / Yu. V. Efremov, A. V. Zimnickij // Lyod i Sneg. - 2017. - № 57(3). - S. 365-372. - Rezhim dostupa: https://doi.org/10.15356/2076-6734-2017-3-365-372.

14. Kalashnikova, $O$. YU. Ispol'zovanie nazemnyh i sputnikovyh dannyh o snezhnom pokrove dlya prognoza stoka reki Naryn [Elektronny] resurs] / O. YU. Kalashnikova, A. A. Gafurov // Lyod i Sneg. - 2017. № 57(4). - S. 507-517. - Rezhim dostupa: https://doi.org/10.15356/2076-6734-2017-4-507-517.

15. Henkel, P., Koch, F., Appel, F., Bach, H., Prasch, M., Schmid, L., et al. (2018). Snow water equivalent of dry snow derived from GNSS carrier phases. IEEE Trans. Geosci. Remote Sens. 56, 3561-3572. https://doi.org/10.1109/TGRS.2018.2802494.

16. Appel, F., Koch, F., Rösel, A., Klug, P., Henkel, P., Lamm, M., et al. (2019). Advances in snow hydrology using a combined approach of GNSS in situ stations, hydrological modelling and earth observation-a case study in Canada. Geosciences 9:44. https://doi.org/ 10.3390/geosciences 9010044 .

17. Masahiro, Hori. A 38-year (1978-2015) Northern Hemisphere daily snow cover extent product derived using consistent objective criteria from satellite-borne optical sensors / Masahiro Hori, Konosuke Sugiura, Kazufumi Kobayashi, Teruo Aoki, Tomonori Tanikawa, Katsuyuki Kuchiki, Masashi Niwano, Hiroyuki Enomoto // Remote Sensing of Environment Volume 191, 15 March 2017, Pages 402-418. 
Вестник Брестского государственного технического университета. 2021

18. Dai, L., Che, T., Ding, Y., and Hao, X. (2017) Evaluation of snow cover and snow depth on the Qinghai-Tibetan Plateau derived from passive microwave remote sensing. The Cryosphere. 11. 19331948. https://doi.org/10.5194/tc-11-1933-2017.

19. Kitaev, L. M. Sezonnaya dinamika temperatury vozduha, snegozapasov i promerzaniya pochvy $v$ central'noj chasti VostochnoEvropejskoj ravniny [Elektronnyj resurs] / L. M. Kitaev, V. A. Ableeva, Zh. A. Asainova, A. S. ZHeltuhin, E. D. Korobov // Lyod i Sneg. 2017. - № 57(4). - S. 518-526. - Rezhim dostupa: https://doi.org/10.15356/2076-6734-2017-4-518-526.

20. Sherstyukov, A. B. Ocenka vliyaniya snezhnogo pokrova na temperaturu poverhnosti pochvy po dannym nablyudenij / A. B. Sherstyukov, O. A. Anisimov // Meteorologiya i gidrologiya. - 2018. - № 2. - S.17-25.

21. Dyukarev, E. A. Vliyanie temperatury vozduha i snezhnogo pokrova na harakteristiki sezonnomerzlogo sloya pochvogruntov / E. A. Dyukarev // Kriosfera Zemli. - 2015. - t. XIX, № 3. - S. 45-51.

22. Loginov, V. F. Vesennie polovod'ya na rekah Belarusi: prostranstvennovremennye kolebaniya i prognoz / V. F. Loginov, A. A. Volchek, An. A. Volchek. - Minsk : Belaruskaya navuka, 2014. - $244 \mathrm{~s}$.

23. Loginov, V. F. Klimat Belarusi / V. F. Loginov. - Minsk : Institut geologicheskih nauk AN Belarusi, 1996. - $234 \mathrm{~s}$.

24. Meshik, O. P. Osobennosti vnutrigodovogo hoda harakteristik snezhnogo pokrova territorii Belarusi / O. P. Meshik, V. A. Morozova, M. V. Borushko // Collection of the International scientific and practical conference «Water resources management in the context of globalization», dedicated to the 105th anniversary of the birth of Professor L. Y. Tazhibaev. - Almaty : KazNARU, 2021. - P. 51-55.

25. Meshik, O. P. Issledovanie transformacii harakteristik snezhnogo pokrova Belarusi kartograficheskimi metodami / O. P. Meshik, V. A. Morozova, M. V. Borushko // Materiali mizhnarodnoï naukovopraktichnoï internet-konferenciï «Suchasnij stan ta perspektivi rozvitku melioraciï zemel'» : do dnya pam'yati doktora geografichnih nauk, profesora Litovchenka O. F., 30 listopada 2020 r. - Dnipro : DDAEU, 2020. - C. 14-17.
26. Shelest, T. A. Izmeneniya harakteristik snezhnogo pokrova Brestskoj oblasti v sovremennyh usloviyah potepleniya klimata / T. A. SHelest, I. V. Shvayuk // Prirodnye i kul'turnye pamyatniki i osnovnye problemy sostoyaniya okruzhayushchej sredy Belarusi i sopredel'nyh stran : mezhvuzovskij sb. nauch. rabot studentov, magistrantov, aspirantov i prepodavatelej geograficheskih fak. BGU i BrGU im. A. S. Pushkina, fak. ekologicheskoj mediciny MGEI im. A. D. Saharova BGU, biologicheskogo fak. VitGU: $v 2$ ch. / BGU [i dr. ; nauch. red. Ya. K. Elovicheva]. - Minsk : BGU, 2019. - C. 560-569.

27. Klimaticheskij kadastr Respubliki Belarus'. Meteorologicheskij ezhemesyachnik. - Minsk : Respublikanskij centr po gidrometeorologii, kontrolyu radioaktivnogo zagryazneniya i monitoringu okruzhayushchej sredy, 1979-2020 gg.

28. Snezhnyj pokrov. CHast' II // Klimaticheskij spravochnik [Elek-tronnyj resurs]. - 2010. - Rezhim dostupa : https://www.pogoda.by/climatdirectory/?page=299. - Data dostupa : 10.05.2021.

29. Volchak, A. Atlas: Weather hazards in Belarus / A. Volchak, Y. Mazhayskiy, A. Meshyk [et al.]. - Moscow : All-Russian Research Institute for Hydraulic Engineering and Land Reclamation, 2017. - 70 r.

30. Tur, V. V. Kartografirovanie osnovnyh harakteristik snegovogo pokrova po rezul'tatam kompleksnoj statisticheskoj obrabotki dannyh meteorologicheskih nablyudenij / V. V. Tur, V. E. Valuev, S. S. Derechennik, O. P. Meshik // Vestnik Brestskogo gosudarstvennogo tekhnicheskogo universiteta. - 2008. - № 2: Vodohozyajstvennoe stroitel'stvo i teploenergetika. - S. 2-10.

31. Meshyk, Aleh. Mapping the Characteristics of Snow Cover in Belarus / Aleh Meshyk, Viktoryia Marozava, Maryna Barushka // 2020 International Conference on Building Energy Conservation, Thermal Safety and Environmental Pollution Control (ICBTE 2020) / E3S Web Conf. Volume 212, 2020. - Brest, Belarus, October 29-30, 2020. https://doi.org/10.1051/e3sconf/202021201013.

Материал поступил в редакцию 14.06.2021 